\title{
PREDICTOR FACTORS FOR CHOLEDOCHOLITHIASIS
}

\author{
Fatores preditores para coledocolitíase
}

Joana TOZATTI, André Luiz Parizi MELLO, Orli FRAZON

From the Hospital Regional Dr. Homero de Miranda Gomes (Regional Dr. Homero de Miranda Gomes Hospital), São José, SC, Brazil.

HEADINGS - Choledocholithiasis, clholelithiasis, jaundice.
ABSTRACT - Background: The choledocolithiasis has an incidence of $8-20 \%$ in patients with cholecystolithiasis. The preoperative diagnosis guides the interventional treatment on the bile duct Aim: To evaluate the sensitivity and specificity of the laboratory markers and imaging studies for choledocholithiasis preoperatively. Methods: The study comprised 254 patients divided into two groups: the control group (207 patients), patients without choledocholithiasis intraoperatively and cases group (47 patients), that enrolled the patients with choledocholithiasis intra-operatively. Were evaluated the laboratory markers, image exams and intra-operative diagnostic aspects. Results: The sample was homogeneous for age and gender. It was observed that $47 \%$ of the cases the patients did not show comorbidities. Hospitalization showes in cases group acute pancreatitis in $12.8 \%$, jaundice in $30 \%$, fever in $30 \%$ and pain in the right hypochondrium in $95 \%$. By comparing them, was observed that fever and jaundice were the signs and symptoms with statistical significance. Patients with choledocholithiasis had transaminases, alkaline phosphatase, gamma-glutamyl transferase and higher bilirubin with statistical significance $(p<0.001)$. In regard to imaging studies, ultrasound was fairly accurate for cholelithiasis and choledocholithiasis $(p<0.001)$. Conclusion: Changes in canalicular and transaminase enzymes are suggestive for preoperative choledocholithiasis; GGT showed better sensitivity and alkaline phosphatase greater specificity; ultrasonography and nuclear magnetic resonance cholangiopancreatography showed high specificity.

\section{Correspondence: \\ Joana Tozatti \\ E-mail: joanatozatti@yahoo.com.br \\ Financial source: none \\ Conflicts of interest: none \\ Received for publication: 13/11/2014 Accepted for publication: 12/02/2015}

DESCRITORES - Coledocolitítase. Cálculos biliares. Icterícia.
RESUMO - Racional: A coledocolitíase tem incidência de 8-20\% em pacientes com colecistolitíase. O diagnóstico pré-operatório orienta o tratamento intervencionista sobre a via biliar Objetivo: Avaliar a sensibilidade e especificidade dos marcadores laboratoriais e exames de imagem para coledocolitíase no pré-operatório. Método: Total de 254 pacientes foi dividido em dois grupos: grupo controle (207 pacientes) com os pacientes que não apresentaram coledocolitíase no intra-operatório e o grupo casos (47 pacientes), que foram os que apresentaram coledocolitíase no intra-operatório. Foram avaliados os marcadores laboratoriais, exames de imagem (ultrassonografia e colangiorresonância) e conclusão intraoperatória para diagnóstico. Resultados: A amostra foi homogênea para sexo e idade. Foi observado que no grupo casos $47 \%$ dos pacientes não apresentaram comorbidades. Quanto ao motivo de internação observou-se no grupo casos que $12,8 \%$ apresentavam pancreatite aguda, 30\% icterícia, 30\% febre e 95\% dor em hipocôndrio direito. Ao comparar os grupos observou-se que febre e icterícia foram o sinal e sintoma com relevância estatística. Os pacientes com coledocolitíase apresentaram transaminases, fosfatase alcalina, gama-glutamil transferase e bilirrubinas mais elevadas com significância estatística $(p<0,001)$. Em relação aos exames de imagem, observou-se que a ultrassonografia demonstrou boa acurácia para colecistolitíase e coledocolitíase $(p<0,001)$. Conclusão: As alterações das enzimas canaliculares e transaminases são sugestivas para investigação pré-operatória de coledocolitíase, sendo que a GGT apresentou melhor sensibilidade e a fosfatase alcalina maior especificidade. A ultrassonografia e a colangioressonância nuclear magnética apresentaram alta especificidade.

\section{INTRODUCTION}

$\mathrm{T}$ he choledocholithiasis has an incidence of $8-20 \%$ in patients with cholelithiasis. The preoperative diagnosis determines the treatment consisting of intervention on the bile duct in three stages: preoperative, intraoperative or postoperative. The intervention can occur via endoscopic or surgical approach. Thus, correct diagnosis is necessary for treatment option. Qualifying scores according to the risk for choledocholithiasis seems to decrease the unnecessary number of procedures ${ }^{10}$.

The association between clinical, laboratory and ultrasound criteria has a sensitivity of $96-98 \%$ for diagnosis. The absence of these criteria takes less than $2 \%$ chance of choledocholithiasis ${ }^{4}$.

The cholecystolithiasis have complications such as cholecystitis, cholestatic syndrome, hepatic abscesses, acute biliary pancreatitis and cholangitis. Chronic obstruction can trigger cirrhosis and portal hypertension. In 10 years of disease, 2-3\% of patients will develop some of these complications. So, it is recommended that all patients who have no surgical contraindication be submitted to cholecystectomy ${ }^{12}$.

For patients with symptomatic gallstones undergoing cholecystectomy with 
possible symptoms correlated to choledocholithiasis, must be instituted intraoperative cholangiography for all patients. If calculi are detected should be performed endoscopic retrograde cholangiopancreatography in the same surgical moment, with common bile duct exploration or transcystic exploration ${ }^{3}$.

This study aims to evaluate the sensitivity and specificity of the laboratory markers and choledocholithiasis imaging results, preoperatively.

METHODS

This study followed the ethical criteria recommended by Resolution 196/96 of the National Health Council (CNS) of the Ministry of Health, and was submitted for approval by the Ethics Committee in Research of the Hospital before its realization.

This is a retrospective study that included all patients of Regional Hospital of São José, SC, Brazil that looked for assistance at the surgical emergency from March 2013 to February 2014. The sample with suspected choledocholithiasis on admission consisted in 254 patients. They were divided into two groups: the control group (207 patients), without choledocholithiasis intraoperatively, and the case group (47 patients), with choledocholithiasis intraoperatively. Search was based on all records, taking in account the operation list performed in the hospital in that period of time. There was no contact with the patient.

The sample obeyed the following inclusion criteria: men and women over the age of 18 with diagnosis or suspicion of cholelithiasis, acute pancreatitis, cholangitis and choledocholithiasis, referenced to general surgery emergency service.

Exclusion criteria were patients undergoing cholecystectomy and those who did not undergo to surgery or had registration error by operation name.

The identified variables were: age, gender, comorbidities, and reason for admission (presence of pain in the right upper quadrant, fever, jaundice, acute pancreatitis). The entry of laboratory tests were analyzed - total bilirubin and fractions, glutamino pyruvic transaminase (SGPT) transaminase glutamino-oxalacetic (AST), gamma-glutamyl transferase (GGT) and alkaline phosphatase (AP). Imaging studies were: total abdominal ultrasound as the presence of gallstones, biliary tract dilatation and choledocholithiasis; CT scan showing dilatation of the bile ducts and the presence of choledocholithiasis; magnetic nuclear resonance cholangiopancreatography with the presence of choledocholithiasis.

Was considered diagnostic of acute pancreatitis when two or more of these criteria were present: 1 ) acute or persistent abdominal/epigastric pain, often radiating to the back; 2) serum amylase or lipase three times the reference value; and 3) characteristic of acute pancreatitis in computed tomography with contrast, ultrasound or nuclear magnetic resonance ${ }^{1}$.

For the diagnosis of cholangitis was taken into consideration the triad of Charcot (pain in the right upper quadrant, fever and jaundice) $)^{7}$. Jaundice was defined as serum total bilirubin greater than $5 \mathrm{mg} / \mathrm{dl}^{11}$. It was considered main bile duct/ common bile duct dilated when it was in caliber greater than $6 \mathrm{~mm}^{6}$.

Regarding complications were considered the ones occurred in the in- and out-patient follow-up till surgical release.

The diagnosis of choledocholithiasis was performed intraoperatively and verified through the surgical descriptions.

As hospitalization time, was considered the day of the surgery until hospital discharge; so, the preoperative hospital stay was not considered, and also not the time as outpatient. Were enrolled only patients who met the inclusion criteria.

Multivariate analysis was performed using SPSS version $17.0^{\circledR}$ from database typed in Microsoft Excel ${ }^{\circledR}$ 2007. The significance level was $95 \%$ ( $p<0.05$ ), with values between $5 \%$ and $10 \%$ considered borderline.

\section{RESULTS}

The sample was homogeneous for age and gender. It was observed that in case group, $47 \%$ of patients showed no comorbidity conditions (Table 1 ).

TABLE 1 - General characteristics of the study population $(n=254)$

\begin{tabular}{|c|c|c|c|}
\hline $\begin{array}{c}\text { General } \\
\text { characteristics }\end{array}$ & $\begin{array}{c}\text { With } \\
\text { choledocholithiasis } \\
\mathrm{n}(\%)\end{array}$ & $\begin{array}{l}\text { Without } \\
\text { choledocholithiasis } \\
\text { (\%) }\end{array}$ & $\mathrm{p}$ \\
\hline & $n=47$ & $n=207$ & \\
\hline Gender & & & 0,649 \\
\hline Female & $29(62)$ & $137(66)$ & \\
\hline Male & $18(38)$ & $72(34)$ & \\
\hline Age* $^{*}$ & $49 \pm 15,7$ & $56 \pm 18,17$ & 0,072 \\
\hline Comorbidities & & & 0,013 \\
\hline HASE & $4(8)$ & $19(9)$ & \\
\hline $\mathrm{HAS}+\mathrm{DM} \Phi$ & $4(8)$ & $23(11)$ & \\
\hline Others & $17(37)$ & $29(15)$ & \\
\hline $\begin{array}{l}\text { Without } \\
\text { comorbidities }\end{array}$ & $22(47)$ & $136(65)$ & \\
\hline
\end{tabular}

${ }^{\mathrm{E}} \mathrm{HAS}=$ systemic arterial hypertension; ${ }^{\circledR} \mathrm{DM}=$ diabetes mellitus; *Values expressed as mean and standard deviation

Regarding the reason for hospitalization, was observed in case group $12.8 \%$ with acute pancreatitis, $30 \%$ jaundice, fever $30 \%$ and $95 \%$ pain in the right hypochondrium. Comparing the two groups it was found that jaundice, and fever were the clinical signs and symptoms with statistical significance (Table 2).

TABLE 2 - Reasons for hospitalization $(n=254)$

\begin{tabular}{|c|c|c|c|}
\hline Hospitalization reasons & $\begin{array}{c}\text { With } \\
\text { choledocholithiasis } \\
\begin{array}{c}n(\%) \\
n=47\end{array}\end{array}$ & $\begin{array}{c}\text { Without } \\
\text { choledocholithiasis } \\
\begin{array}{c}n(\%) \\
n=207\end{array}\end{array}$ & $p$ \\
\hline $\begin{array}{l}\text { Cholangitis } \\
\text { Yes } \\
\text { No }\end{array}$ & $\begin{array}{c}9(19) \\
38(81)\end{array}$ & $\begin{array}{c}1(1) \\
206(99)\end{array}$ & $<0,001$ \\
\hline $\begin{array}{l}\text { Pain on right hypochondrium } \\
\text { Fever } \\
\text { Jaundice }\end{array}$ & $\begin{array}{l}45(95) \\
14(30) \\
14(30)\end{array}$ & $\begin{array}{l}203(98) \\
26(12) \\
6(3)\end{array}$ & $\begin{array}{c}0,344 \\
0,003 \\
<0,001\end{array}$ \\
\hline Biliar acute pancreatitis & $6(12,8)$ & $182(87)$ & 0,896 \\
\hline
\end{tabular}

Patients with choledocolithiasis had transaminases, alkaline phosphatase, higher gamma-glutamyl transferase and bilirubin than the group without choledocolithiasis with statistical significance (Table 3 ).

It is observed that AST, ALT and alkaline phosphatase showed similar sensitivity, but only alkaline phosphatase showed high specificity. GGT showed high sensitivity (93\%) but low specificity (63\%) (Table 4).

With regard to imaging tests, it was observed that ultrasound had good accuracy for cholelithiasis and choledocolithiasis $(p<0.001)$, but with low positive predictive value (Table 5). 
TABLE 3 - Results of laboratory tests of the analyzed population $(n=254)$

\begin{tabular}{|c|c|c|c|}
\hline Exams & $\begin{array}{l}\text { With } \\
\text { choledocholithiasis } \\
n=47\end{array}$ & $\begin{array}{c}\text { Without } \\
\text { choledocholithiasis } \\
n=207\end{array}$ & $p$ \\
\hline $\mathrm{TGO}^{1 *}$ & $68 \pm 68,7$ & $38 \pm 69,7$ & 0,003 \\
\hline $\mathrm{TGP}^{2 \star}$ & $92 \pm 70,8$ & $42 \pm 67,9$ & 0,001 \\
\hline $\mathrm{GGT}^{3 *}$ & $452 \pm 561,4$ & $105 \pm 184,3$ & 0,013 \\
\hline $\begin{array}{l}\text { Alcaline } \\
\text { phosphatase* }\end{array}$ & $202 \pm 238,1$ & $92 \pm 67,9$ & 0,002 \\
\hline $\begin{array}{l}\text { Total bilirrubin* } \\
\text { Direct } \\
\text { Indirect }\end{array}$ & $\begin{array}{l}2,33 \pm 5,03 \\
1,66 \pm 3,5 \\
0,81 \pm 2,4\end{array}$ & $\begin{array}{l}0,81 \pm 2,1 \\
0,08 \pm 1,17 \\
0,51 \pm 2,81\end{array}$ & $\begin{array}{l}0,004 \\
0,001 \\
0,006\end{array}$ \\
\hline
\end{tabular}

${ }^{1} \mathrm{TGO}=$ transaminase glutamino-oxalacetic; ${ }^{2} \mathrm{TGP}=$ transaminase glutamino piruvic; ${ }^{3} \mathrm{GGT}=$ gama-glutamil transferase *Values expressed as mean and standard deviation

TABLE 4 - Presence or absence of laboratory abnormalities and their sensitivity and specificity for the diagnosis of choledocolithiasis $(n=254)$

\begin{tabular}{|c|c|c|c|c|c|}
\hline Exams & $\begin{array}{c}\text { Sensibility } \\
\%\end{array}$ & $\begin{array}{c}\text { Specificity } \\
\%\end{array}$ & $p^{*}$ & VPP£ & VPN屯 \\
\hline TGO $^{1}$ & 70 & 68 & 0,043 & 0,33 & 0,90 \\
\hline TGP $^{2}$ & 74 & 59 & 0,050 & 0,29 & 0,91 \\
\hline Alcaline phosphatase & 78 & 99 & 0,039 & 0,90 & 0,84 \\
\hline GGT $^{3}$ & 93 & 63 & 0,042 & 0,25 & 0,96 \\
\hline Total bilirubin & 29 & 97 & 0,050 & 0,70 & 0,86 \\
\hline
\end{tabular}

${ }^{1} \mathrm{TGO}=$ transaminase glutamino-oxalacetic; ${ }^{2} \mathrm{TGP}=$ transaminase glutaminopiruvic; ${ }^{3} \mathrm{GGT}=$ gama-glutamil transferase; *values given by the ROC curve (Receiver Operating Characteristic); ${ }^{\text {E}}$ positive predictive value; ${ }^{\circledR}$ negative predictive value

TABLE 5 - Imaging tests performed $(n=254)$

\begin{tabular}{|c|c|c|c|c|c|}
\hline Exams & $\begin{array}{c}\text { With } \\
\text { choledocholithiasis } \\
n=47\end{array}$ & $\begin{array}{c}\text { Without } \\
\text { choledocholithiasis } \\
n=207\end{array}$ & $p$ & VPP* & $\mathrm{VPN}^{\star *}$ \\
\hline $\begin{array}{l}\text { USG }^{1} \\
\text { Colelithiasis } \\
\text { Biliary dilatation } \\
\text { Choledocholithiasis }\end{array}$ & $\begin{array}{l}29(61) \\
17(36) \\
16(34)\end{array}$ & $\begin{array}{c}192(92) \\
16(7) \\
9(4)\end{array}$ & $\begin{array}{l}0,001 \\
0,046\end{array}$ & $\begin{array}{c}- \\
0,51 \\
0,64\end{array}$ & $\begin{array}{c}- \\
0,86 \\
0,86\end{array}$ \\
\hline $\begin{array}{l}\mathrm{TC}^{2} \\
\text { Biliary dilatation } \\
\text { Choledocholithiasis }\end{array}$ & $\begin{array}{l}16(34) \\
14(29)\end{array}$ & $\begin{array}{l}13(6) \\
2(1)\end{array}$ & 0,001 & $\begin{array}{l}0,55 \\
0,87\end{array}$ & $\begin{array}{l}0,86 \\
0,86\end{array}$ \\
\hline $\begin{array}{l}\text { CholangioRNM }^{3} \\
\text { Choledocholithiasis }\end{array}$ & $29(61)$ & 5 (2) & 0,001 & 0,73 & 0,91 \\
\hline
\end{tabular}

ColangioRNM = nuclear cholangioresonance; ${ }^{1} \mathrm{USG}=$ ultrasonography ${ }^{2} \mathrm{TC}=$ abdominal tomography; ${ }^{3 *}$ positive predictive value; ${ }^{* *}$ negative predictive value

Ultrasonography had a sensitivity of $34 \%$ and specificity of $95 \%$ for the diagnosis of choledocholithiasis (with $95 \% \mathrm{CI}$, $\mathrm{p}=0.46)$. Regarding the tomography, the results of sensitivity and specificity were $55 \%$ and $86 \%$ respectively. Cholangioresonance had $73 \%$ sensitivity and $91 \%$ specificity.

The most used surgical procedure was cholecystectomy, due to 207 patients showed no calculi evidence. Only one cholecystectomy was performed with choledocholithiasis evidence in imaging exams, being held endoscopic retrograde cholangiopancreatography postoperatively.

For patients with choledocholithiasis in imaging, the most widely used laparoscopic procedure was cholecystectomy associated to choledochotomy.

Postoperative complications were higher in the group with choledocholithiasis, with statistical significance (Table 6).

Patients with choledocolithiasis had discharged an average of 9.21 days (variance 7.02) and no choledocolithiasis with an average of 3.71 days (variance 6.94) $(p=0.18)$.
TABLE 6 - Postoperative complications of the operations performed for patients with cholelithiasis and choledocholithiasis $(n=254)$

\begin{tabular}{|c|c|c|c|}
\hline $\begin{array}{l}\text { Postoperative } \\
\text { complications }\end{array}$ & $\begin{array}{c}\text { With } \\
\text { choledocholithiasis } \\
n=47\end{array}$ & $\begin{array}{c}\text { Without } \\
\text { choledocholithiasis } \\
n=207\end{array}$ & $p$ \\
\hline $\begin{array}{l}\text { Residual calculi } \\
\text { Biliary fistula } \\
\text { Infection in surgical site } \\
\text { Pulmonary } \\
\text { complications } \\
\text { Urinary complications } \\
\text { Death } \\
\text { Others } \\
\text { No complications }\end{array}$ & $\begin{array}{c}3(6) \\
3(6) \\
4(8) \\
1(2) \\
0(0) \\
3(6) \\
0(0) \\
33(34)\end{array}$ & $\begin{array}{c}0(0) \\
4(2) \\
11(5) \\
2(1) \\
2(1) \\
3(1) \\
7(3) \\
181(87)\end{array}$ & 0,001 \\
\hline
\end{tabular}

DISCUSSION

This paper presented homogeneous sample; by gender, it was different from the literature ${ }^{9}$; for age, showed no differences to the already was published. Among the comorbidities, Citra et al refer as associated factors diabetes mellitus, obesity and dyslipidemia with statistical significance, which disagrees with the present study that, although the sample had statistical significance, showed no specific comorbidity related to choledocolithiasis ${ }^{2,5}$.

Fields et al. (2004) presented a study with 23 cases of choledocholithiasis without cholangitis or acute pancreatitis, which differs from the population studied in this paper ${ }^{2.4}$.

It was observed that patients with choledocholithiasis showed elevation of bilirubin; but what stood out most was increased GGT. Citra et al found that alkaline phosphatase was altered in $98 \%$ of cases, which differs from the present study ${ }^{5}$. Fields et al. (2004) showed similar results, with transaminases changing significatively ${ }^{4}$.

Citra et al. showed that ultrasonography had a sensitivity of $73.3 \%$ and specificity of $95 \%$ for choledocholithiasis. These results conflict with the present study. This discrepancy can be attributed by being the exam operator dependent and that technical difficulty may vary according to the patient body type, which is not addressed in this study ${ }^{5,2}$.

According to William et al (2009), nuclear magnetic colangiopancreatoresonance has a sensitivity of $85 \%$ and specificity of $93 \%$, which corroborates with these findings. These authors present the CT with a specificity of $65-93 \%$ which emphasizes the heterogeneity of the studies over computed tomography as diagnostic method for pre-operative choledocholithiasis ${ }^{12,6}$.

Choledocholithiasis treatment differs in main bile duct calculi guidelines. William et al (2009) show that patients with it should undergo endoscopic retrograde cholangiopancreatography preferably at the same time of cholecystectomy. In service where this study was prepared this type of therapy is not available; one patient was referred to another hospital for resolution of symptoms after cholecistectomy ${ }^{12}$.

CONCLUSION

Changes in canalicular and transaminase enzymes are suggestive for preoperative choledocholithiasis; GGT showed better sensitivity and alkaline phosphatase greater specificity; ultrasonography and nuclear magnetic resonance cholangiopancreatography showed high specificity.

\section{REFERENCES}

1. Banks PA, Bollen $T L$, Dervenis $C$, Gooszen HG, Johnson $C D$, Sarr MG, Tsiotos GG, Vege SS; Acute Pancreatitis Classification Working Group. Classification of acute pancreatitis--2012: revision of the Atlanta classification and definitions by international consensus. Gut. 2013 Jan;62(1):102-11. 
2. BeckerBA, Chin E, MervisE, Anderson CL, Oshita MH, FoxJC. Emergency biliary sonography: utility of common bile duct measurement in the diagnosis of cholecystitis and choledocholithiasis. J Emerg Med. 2014 Jan;46(1):54-60

3. Brown LM, Rogers SJ, Cello JP, Brasel KJ, Inadomi JM. Cost-effective treatment of patients with symptomatic cholelithiasis and possible common bile duct stones. J Am Coll Surg. 2011 Jun;212(6):1049 1060.e1-7.

4. Campos T, Parreira JG, de Moricz A, Rego RE, Silva RA, Pacheco Junior AM. Predictors of choledocholithiasis in patients sustaining gallstones Rev Assoc Med Bras. 2004 Apr-Jun;50(2):188-94. Epub 2004 Jul 21.

5. Torres OJM, Cintra JCA, Cantanhede EB, Melo TCM, Macedo EL, Dietz UA. Ultrasonography value and of alkaline phosphatase in choledocholithiasis diagnosis. JBM 73(4):42-46, 1997.

6. Costi R, Gnocchi A, Di Mario F, Sarli L. Diagnosis and management of choledocholithiasis in the golden age of imaging, endoscopy and laparoscopy. World J Gastroenterol. 2014 Oct 7;20(37):13382-401.
7. Goldman L, Ausiello D. Tratado de medicina interna: cecil. 22. ed. Rio de Janeiro: Elsevier, 2005.

8. Mertens MC, Roukema JA, Scholtes VP, De Vries J. Risk assessment in cholelithiasis: is cholecystectomy always to be preferred? J Gastrointest Surg. 2010 Aug;14(8):1271-9.

9. Parreira JG, Rego RE, Campos TD, Moreno CH, Pacheco AM Jr, Rasslan S. Predictors of choledocholithiasis in patients sustaining acute biliary pancreatit Predictors of choledocholithiasis in patients sustaining acute biliary pancreatit. Rev Assoc Med Bras. 2004 OctDec;50(4):391-5.

10. Targarona EM, Bendahan GE. Management of common bile duct stones: controversies and future perspectives. HPB (Oxford). 2004;6(3):140-3.

11. Townsend CM. Tratado de cirurgia. 19ed. 2006

12. Williams EJ, Green J, Beckingham I, Parks R, Martin D, Lombard M; British Society of Gastroenterology. Guidelines on the management of common bile duct stones (CBDS). Gut. 2008 Jul;57(7):1004-21. 